\title{
鉛直スチフナ形式・SRC 柱-S はり接合部の 力学的挙動に関する研究 \\ STRUCTURAL BEHAVIORS OF STEEL-BEAM TO SRC-COLUMN CONNECTIONS REINFORCED WITH VERTICAL STIFFENING PLATES
}

\author{
森田耕次*, 横山幸夫**, 平岡秀章**, 石井匠** \\ Koji MORITA, Yukio YOKOYAMA, Hideaki HIRAOKA and Takumi ISHII
}

\begin{abstract}
Experimental and analytical studies have been carried out to estimate yield and ultimate strength of steel-beam to SRC-column connections where steel element of SRC is cross-H section and reinforced with vertical stiffening plates. The followings can be concluded from this research.

(1) From the test results of cruciform tensile specimens,

i. The effect of infilled-concrete is to change the stress transfer mechanism of vertical stiffening plate. The yield mode of vertical stiffening plate is the out-plane bending one in steel column, but the tensile yielding one in both steel-concrete column and steel-reinforced-concrete (SRC) column.

ii. The strength of connections became stronger with the thickness of vertical stiffening plate and column flange, but it did not become stronger by widening vertical stiffening plate beyond its specified limit.

iii. The yield and ultimate strength of cruciform connections can be estimated by the proposed analysis based on the yield line theory taking the difference of structural system of column into consideration.

(2) From the test results of steel-beam and SRC-column subassemblage tests,

i. Similar yield strength and deformation behavior were observed between the tension side and the compression side of beam-flange to SRC-column connection.

ii. The yield and ultimate strength of beam-end-connection can also be estimated analytically based on the yield line theory.

iii. The yield strength of connection panel can be estimated by modifying the formula presented in AIJ Standard.
\end{abstract}

Keywords : SRC Column, Steel Beam, Connection, Yield Strength, Ultimate Strength

\section{1. 序}

鉄骨鉄筋コンクリート柱-鉄骨はり構造の柱貫通形式 柱はり接合部として，柱の鉄骨が断面の場合は水平ス チフナ形式と鉛直スチフナ形式が考えられる。鉛直スチ フナ形式は水平スチフナ形式で問題とされる接合部にお けるコンクリートの充てん性は良好で，また，接合部の 溶接施工の工数は大幅に低減される。

しかし，鉛直スチフナ形式では「はりフランジの応力 は，柱鉄骨ウェブと鉛直スチフナによって柱内に伝達さ れることになるが，応力の流れに無理がある」との指摘 がある”。また，柱はり接合部の力学的挙動に関する実
験および研究はほとんどなされておらず，接合部の耐力 評価についてはいまだ明確な方法は示されていない。 本研究では, 各種構造形式の柱と鉄骨はり引張側フラ ンジの鉛直スチフナ形式接合部に関する部分モデル実験 の結果に基づき, 降伏線理論により接合部耐力を考察し た。また，十字形・部分骨組架構の実験結果より鉛直ス チフナ形式・柱はり接合部の応力伝達機構を考察し, 部 分モデル実験により得られた接合部耐力の評価法が骨組 架構の柱はり接合部に適用できることを検証している。 なお，本研究の成果の一部は文献 2)に示している。
* 千葉大学 教授. 工博

** 千葉大学 大学院生
Prof. of Chiba Univ., Dr. Eng.

Graduate Student of Chiba Univ. 


\section{2. 部分モデル実験による検討}

\section{1 試験体}

各種構造形式の柱と鉄骨はり引張側フランジの鉛直ス チフナ形式接合部に関する部分モデル実験を計画した。 試験体の形状は，図一1に示すとおり，柱鉄骨が整形な ஐ断面で柱鉄骨フランジの幅とはりフランジの幅が同一 の場合に限定している。実験で採用した柱の構造形式は 鉄骨構造 (S)，鉄骨コンクリート構造 (SC)，鉄骨鉄 筋コンクリート構造 (SRC) の 3 形式である。ここで, SC とは柱の鉄骨フランジと鉛直スチフナによって囲ま れた部分に充てんコンクリートを打設した構造である。 柱が SC とSの実験結果を比較して柱の充てんコンク リートが接合部の応力伝達で果たす役割を検討し，柱が $\mathrm{SC}$ と SRC の実験結果を比較して SRC 柱の被覆鉄筋 コンクリート部分が接合部耐力に与える寄与を検討す る。その他の実験因子としては，鉛直スチフナの幅 $\left({ }_{s} h\right)$ と厚さ $\left(_{s} t\right)$ および柱鉄骨フランジ厚さ $\left(_{c} t_{s}\right)$ である。試 験体はこれらの実験因子を組み合わせた表一1に示す $\mathrm{S}$ : 1 体, SC：5 体, SRC：5 体の合計 11 体とした。使 用材料は鋼板が SS 41，鉄筋はSD 30，コンクリートは 普通コンクリートであり，それらの機械的性質を表一2 に示す。
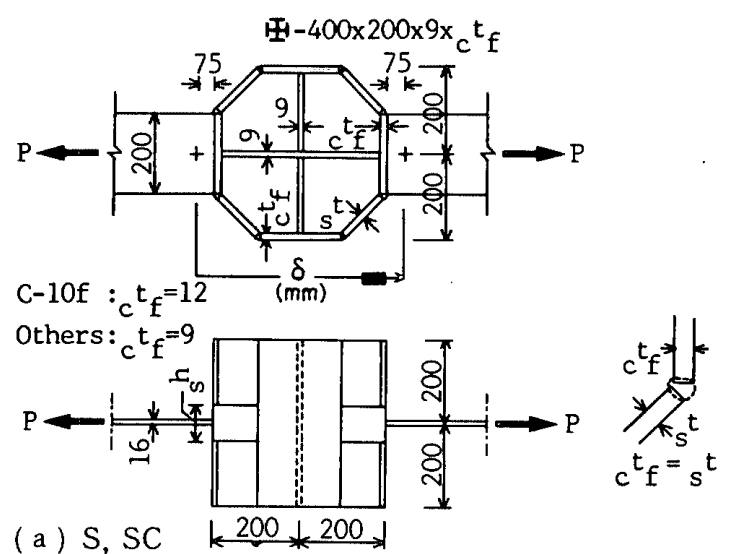

(a) S, SC
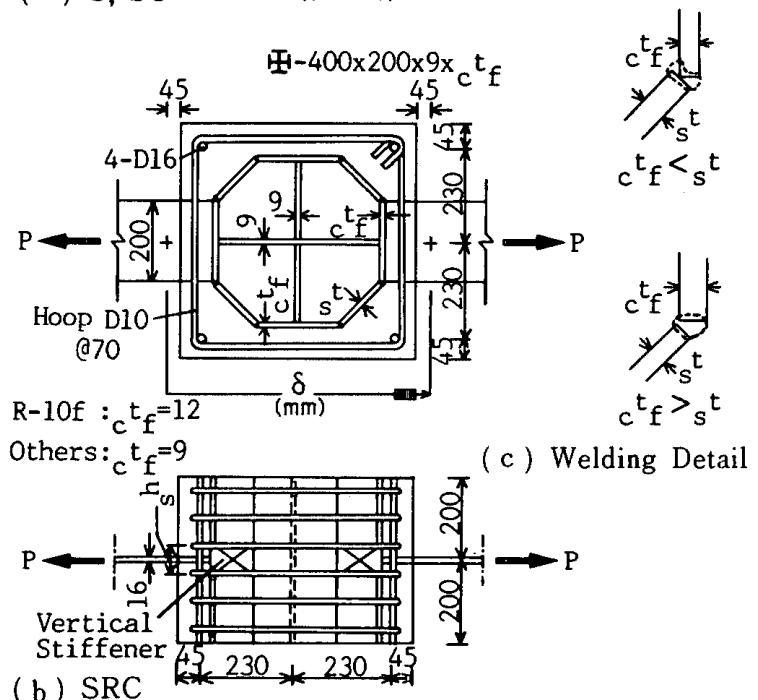

Fig. 1 Geometry of Cruciform Specimens
なお, 載荷は単調引張載荷とした。接合部の荷重 $(P)-$ 局部変形 $(\Delta)$ 関係を図一1に取り付け位置を示す変位計 を用いて求め，また，接合部各部のひずみ度をストレイ ンゲージにより測定した。

\section{2 実験結果}

各試験体の $P-\Delta$ 曲線を図一 2 に, 全塑性耐力 $\left({ }_{e} P_{\rho}\right)$ お よび最大耐力 $\left({ }_{e} P_{m}\right)$ を表一 3 に示す。ここで, ${ }_{e} P_{\rho}$ は図 一3に示す General Yield Point 法により求めた。なお, 図一 3 に示す第一折線は $P-\Delta$ 曲線上の ${ }_{e} P_{m} / 3$ における 接線で, 第二折線は $P-\Delta$ 曲線上の $(1 / 4 \sim 1 / 2){ }_{e} \Delta_{m}\left(e_{e} \Delta_{m}\right.$ は ${ }_{e} P_{m}$ での局部変形量）における接線である。このよ うにして求めた各試験体の ${ }_{e} P_{p}$ での㴊性は ${ }_{e} P_{m} / 3$ にお ける剛性の約 $1 / 9 \sim 1 / 13$ となるが, 局部変形量 $\left({ }_{e} \Delta_{\rho}\right)$ は ${ }_{e} \Delta_{\rho} /{ }_{c} t_{f}=0.18 \sim 0.36$ と過大な值ではない。

Table 1 Dimensions and Test Parameters of Cruciform Specimens

\begin{tabular}{|c|c|c|c|}
\hline & & $\begin{array}{c}\text { Column } \\
\text { A- }{ }_{c} \mathrm{Hx}_{c} b x_{c} t_{w} x_{c} t_{f}\end{array}$ & $\begin{array}{c}\text { Verti. Stiff. } \\
s_{s} x_{s}\end{array}$ \\
\hline$\omega$ & $\mathrm{N}-10 \mathrm{e}$ & $400 \times 200 \times 9 \times 9$ & $9 \times 80$ \\
\hline U & $\begin{array}{l}c-10 \mathrm{e} \\
c-10 \mathrm{~s} \\
\mathrm{c}-10 \mathrm{f} \\
\mathrm{c}-05 \mathrm{e} \\
\mathrm{c}-20 \mathrm{e}\end{array}$ & $\begin{array}{c}\text { ditto } \\
\text { ditto } \\
400 \times 200 \times 9 \times 12 \\
400 \times 200 \times 9 \times 9 \\
\text { ditto }\end{array}$ & $\begin{array}{l}\text { ditto } \\
16 \times 80 \\
9 \times 100 \\
9 \times 40 \\
9 \times 160 \\
\end{array}$ \\
\hline $\begin{array}{l}\text { \& } \\
\mathbb{5}\end{array}$ & $\begin{array}{l}R-10 e \\
R-10 s \\
R-10 f \\
R-05 e \\
R-20 e\end{array}$ & $\begin{array}{l}\text { ditto } \\
\text { ditto } \\
400 \times 200 \times 9 \times 12 \\
400 \times 200 \times 9 \times 9 \\
\text { ditto }\end{array}$ & $\begin{array}{r}9 \times 80 \\
16 \times 80 \\
9 \times 100 \\
9 \times 40 \\
9 \times 160 \\
\end{array}$ \\
\hline
\end{tabular}

Table 2 Mechanical Properties of Materials

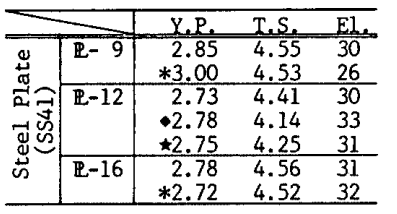

Y.P.; Yield Point $\left[\mathrm{tf} / \mathrm{cm}^{2}\right]$ T.S.;Tensile Strength[tf $\left./ \mathrm{cm}^{2}\right]$

E1. ; Percentage Elongation $[\%]$

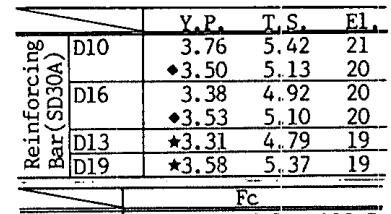
FC ;Compressive Strength $\left[\mathrm{kgf} / \mathrm{cm}^{2}\right] \quad \begin{gathered}* ; \mathrm{R}-10 \mathrm{e}, \mathrm{R}-10 \mathrm{~s}, \mathrm{R}-20 \mathrm{e} \\ \text { IR-10e, IR-10s, IR-10f }\end{gathered}$

Table 3 Test Results of Cruciform Specimens

\begin{tabular}{|c|c|c|c|c|c|}
\hline & & $\begin{array}{r}\text { Genera } \\
\text { Str } \\
\mathrm{e}^{\mathrm{P}_{\mathrm{p}}[\mathrm{tf}]} \\
\end{array}$ & $\begin{array}{l}\text { ield } \\
\text { th } \\
{ }_{p}^{\prime} t_{f}\end{array}$ & $\begin{array}{l}\text { Maximum } \\
\text { Strength } \\
\mathrm{e}^{\mathrm{P}}[\mathrm{tf}]\end{array}$ & $\begin{array}{l}\text { Crack } \\
\text { Pa.ttern }\end{array}$ \\
\hline us & $\mathrm{N}-10 \mathrm{e}$ & 48.4 & 0.36 & 70.0 & $\mathrm{CF}$ \\
\hline u & $\begin{array}{l}c-10 \mathrm{e} \\
c-10 s \\
c-10 f \\
c-05 e \\
c-20 e\end{array}$ & $\begin{array}{l}66.4 \\
80.0 \\
81.6 \\
49.6 \\
63.2\end{array}$ & $\begin{array}{l}0.35 \\
0.32 \\
0.32 \\
0.23 \\
0.20\end{array}$ & $\begin{array}{r}94.6 \\
105.6 \\
121.0 \\
69.8 \\
88.0\end{array}$ & $\begin{array}{l}\mathrm{CF}, \mathrm{BF} \\
\mathrm{CF}, \mathrm{BF} \\
\mathrm{CW} \\
\mathrm{CF} \\
\mathrm{CF}, \mathrm{BF}\end{array}$ \\
\hline 吠 & $\begin{array}{l}R-10 e \\
R-10 s \\
R-10 f \\
R-05 e \\
R-20 e\end{array}$ & $\begin{array}{l}70.8 \\
85.7 \\
83.9 \\
54.0 \\
82.6\end{array}$ & $\begin{array}{l}0.35 \\
0.23 \\
0.18 \\
0.24 \\
0.23\end{array}$ & $\begin{array}{r}102.8 \\
132.2 \\
130.1 \\
84.0 \\
121.2\end{array}$ & $\begin{array}{l}\mathrm{CW} \\
\mathrm{CW}, \mathrm{BF} \\
\mathrm{CW}, \mathrm{CD} \\
\mathrm{CF} \\
\mathrm{CW}, \mathrm{CD}\end{array}$ \\
\hline
\end{tabular}



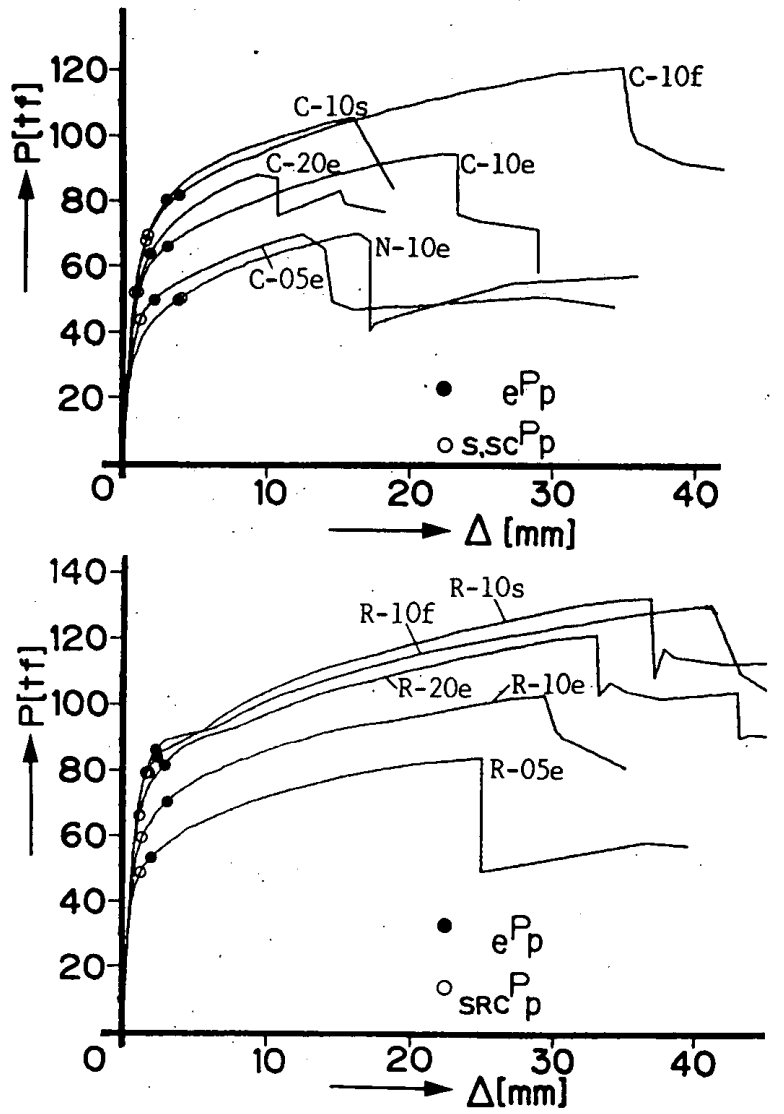

Fig. 2 Experimental $P$ - $\Delta$ Relationships of Cruciform Specimens

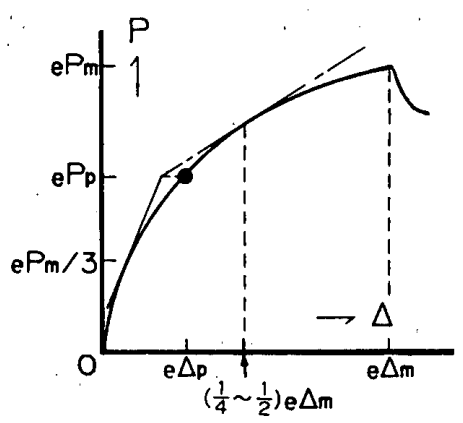

Fig. 3 Definition of General Yield Strength $\left({ }_{e} P_{p}\right)$ for Experimentál $P-\Delta$ Relationships
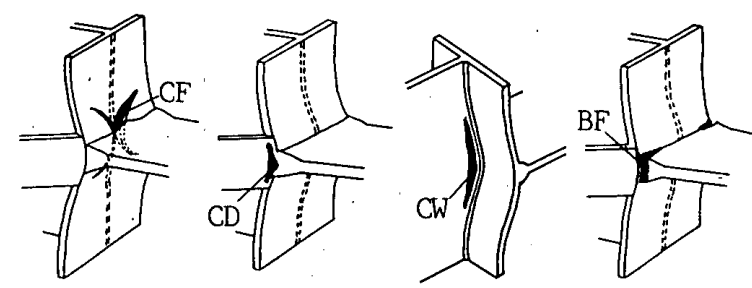

Fig. 4 Crack Pattern in Beam Flange Joint

接合部には図一 4 に示す 4 種類の亀裂 $\mathrm{CF}, \mathrm{CD}, \mathrm{CW}$ および BF が観察された（表一3参照）。以下に，柱の 構造形式別に, 接合部の力学的挙動を示す。

（1）柱：鉄骨構造 (S)

試験体 N-10e の各部のひずみ分布を図-5に示す。
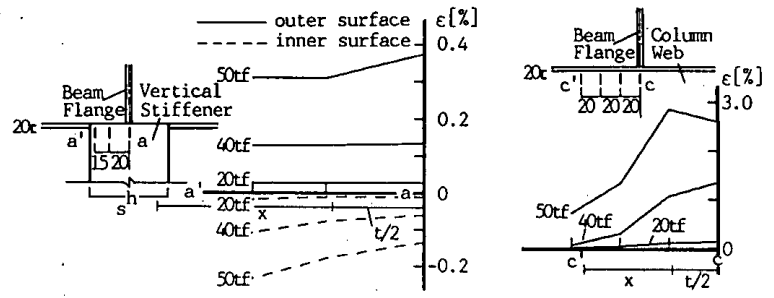

(a) Vertical Stiffener

(c) Column Web
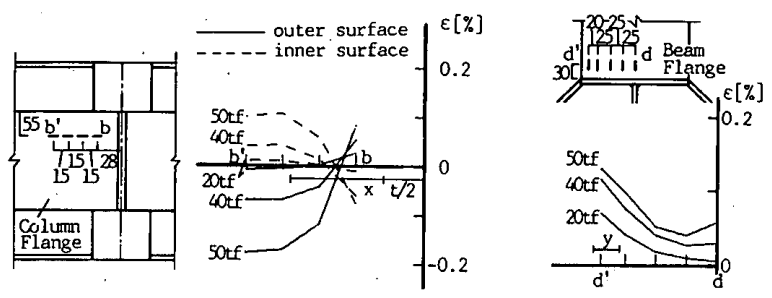

(b) Column Flange

(d) Beam Flange

Fig. 5 Strain Distributions in $\mathrm{N}-10 \mathrm{e}$

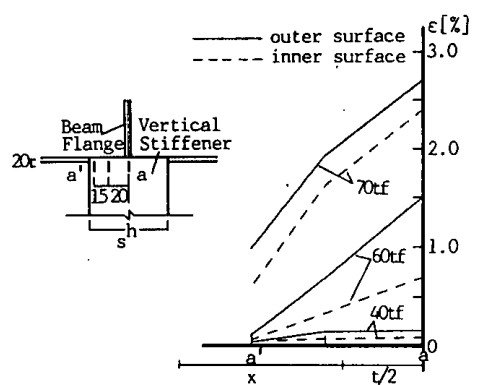

(a) Vertical Stiffener

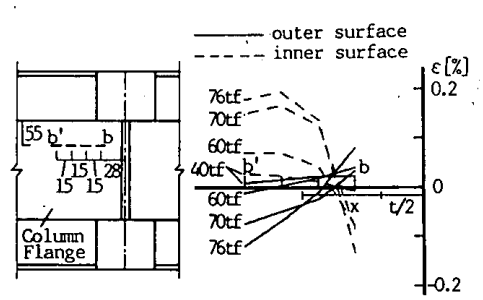

(b) Column Flange

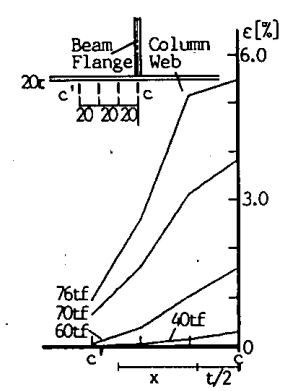

(c) Column Web

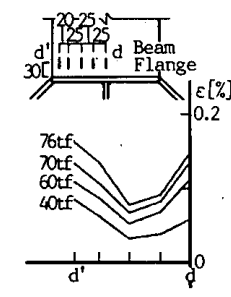

(d) Beam Flange
Fig. 6 Strain Distributions in $\mathrm{C}-10 \mathrm{e}$

各部の降伏順序は柱ウェブの引張降伏, 柱フランジ（直 交フランジも含む）の面外曲げ降伏, 鉛直スチフナの面 外曲げ降伏，はりフランジの引張降伏の順となり, ${ }_{e} P_{p}$ は鉛直スチフナが面外曲げ降伏する荷重とほぼ対応して いる。

（2）柱：鉄骨コンクリート構造（SC）

試験体 C-10e の各部のひずみ分布を図一6に，また， 各試験体の鉛直スチフナのひずみ分布を図一7に示す。 鉄骨各部の降伏順序は柱鉄骨ウェブの引張降伏, 鉛直ス チフナの引張降伏, 柱鉄骨フランジの面外曲げ降伏, は りフランジの引張降伏の順であるが, 試験体 C-10 s お よび C-10 f に関しては, 柱鉄骨フランジの面外曲げ降 伏とはりフランジの引張降伏がほぼ同時に起こってい る。また, $e P \rho$ は柱鉄骨フランジが面外曲げ降伏する荷 重とほぼ対応している。なお，鉛直スチフナは，shが 広い C-20e が局部的に引張降伏しているのに対し, 他 


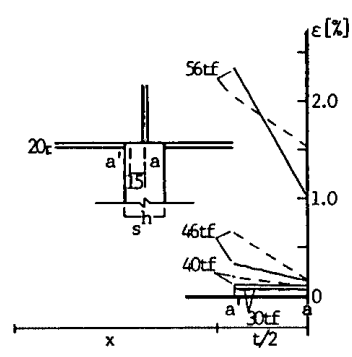

(a) $\mathrm{C}-05 \mathrm{e}$

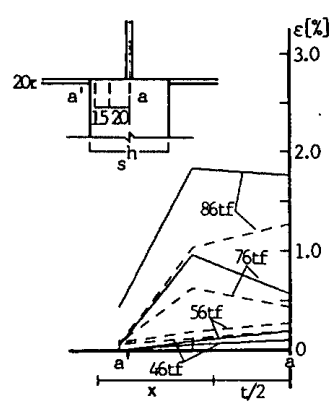

(b) $\mathrm{C}-10 \mathrm{~s}$

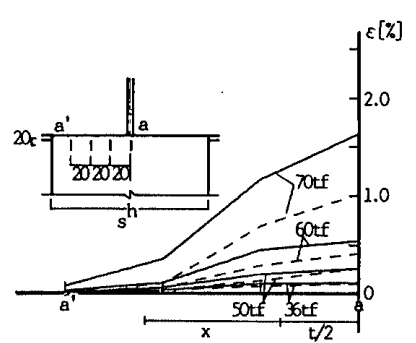

(c) $\mathrm{C}-20 \mathrm{e}$

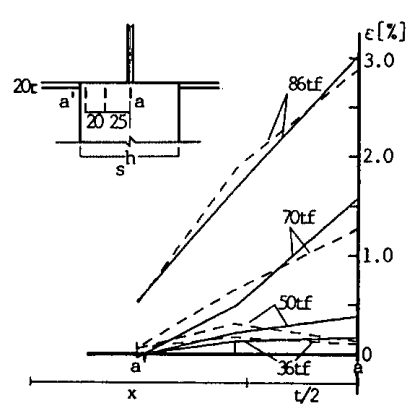

(d) $\mathrm{C}-10 \mathrm{f}$
Fig.7 Strain Distribution in Vertical Stiffeners

の試験体は全面引張降伏している (図一7参照)。

柱の構造形式だけが相違する C-10e と N-10e を比 較すると, 鉛直スチフナの降伏形が C-10e は引張降伏 であるのに対して N-10e は面外曲げ降伏である（図一 5(a)，6(a) 参照)。また， C-10e は全塑性および最大 耐力とも $\mathrm{N}-10 \mathrm{e} の 1.37,1.35$ 倍となっている。したがっ て, 接合部の応力伝達機構および耐力に及ぼす充てんコ ンクリートの効果は大きい。

鉛直スチフナ幅 $(s h)$ だけが相違する C- $05 \mathrm{e}, \mathrm{C}-10 \mathrm{e}$, $\mathrm{C}-20 \mathrm{e}$ を以下に比較する。 $s h$ の狭い C-05e が C-10 e に比べ, 早期に剛性の低下がみられ, 全塑性および最大 耐力はともに約 0.75 倍であった。これに対して ${ }_{s} h$ の 広い C- 20 e は C $-10 \mathrm{e}$ に比べ全塑性および最大耐力と もに若干下回った。したがって，鉛直スチフナ幅がある 特定の幅以上になると接合部耐力の上昇は期待できな い。

鉛直スチフナ厚さ $\left.l_{s} t\right)$ だけが相違する $\mathrm{C}-10 \mathrm{~s}$ と C$10 \mathrm{e}$ を比較すると, st が厚い C $-10 \mathrm{~s}$ の全塑性および最 大耐力は C-10e の 1.2, 1.1 倍であった。また, 柱フ ランジ厚さ $\left.{ }_{c} t_{f}\right)$ だけが相違するC $-10 \mathrm{f}$ と $\mathrm{C}-10 \mathrm{e}$ を比 較すると、 $c t_{s}$ が厚い C-10 f の全塑性および最大耐力 は C-10e の 1.2，1.3 倍であった。

(3) 柱: 鉄骨鉄筋コンクリート (SRC)

試験体の鉄骨各部のひずみ分布および降伏順序は柱が SC の試験体と同様である。また, 被覆鉄筋コンクリー 卜部分は, 柱フランジが面外曲げ降伏を開始する荷重と 前後して,はりフランジ端より斜めひび割れが発生し(図 -8 参照),$e P_{\rho}$ 以後に帯筋がはりフランジが取り付く側 で降伏する。しかし，主筋は， ${ }_{e} P_{m}$ まで降伏していない。
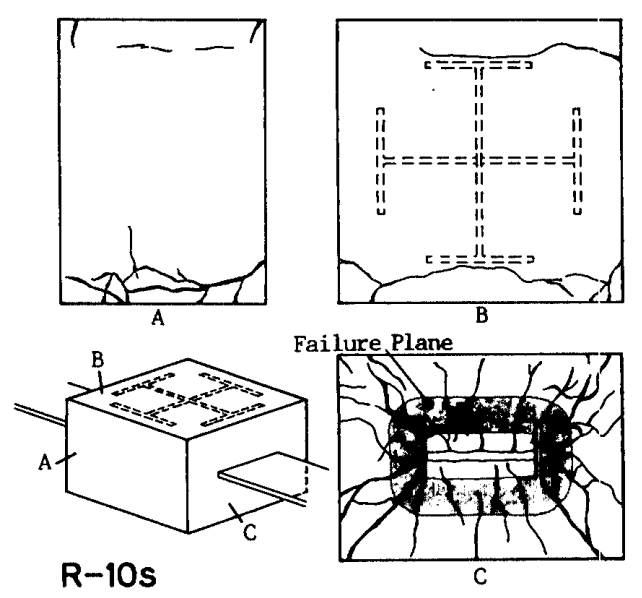

Fig. 8 Crack Pattern in Concrete of R-10 s

柱の構造形式だけが相違する R-10e と C- $10 \mathrm{e}, \mathrm{R}-$ 05 e と C-05e および R-20 e と C-20 e を比較すると, 前者は後者に対して全塑性耐力で 1.07 から 1.31 倍, 最 大耐力で 1.09 から 1.38 倍となり，被覆鉄筋コンクリー 卜部分の接合部耐力に対する寄与が認められる。

\section{3 接合部耐力の解析}

接合部の全塑性耐力時では, 柱の構造形式にかかわら ず，柱鉄骨フランジははりフランジ取り合い位置近傍で 面外曲げ降伏を起こしている。柱鉄骨フランジの面外曲 げ抵抗が接合部の降伏耐力に与える寄与を評価する上で

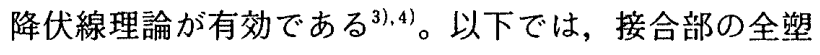
性耐力を柱の構造形式別に降伏線理論により解析し, 得 られた全塑性耐力の評価式を最大耐力の評価まで拡張し て適用する方法について検討する。

\section{（1）柱：鉄骨構造 (S)}

接合部の全塑性耐力を, 試験体 N-10e のひずみ分布 を参照して, 図一9の崩壊機構を仮定して解析する。す なわち, 解析に用いた主な仮定は以下のとおりである。

i ）はりフランジ端部は応力集中により引張降代域が雨 端に区間 $y$ だけ生じ，その区間で柱フランジの面外曲 げ変形が許容される4)。ここで, $y$ は未知数である。

ii）柱ウェブは応力集中により引張降伏域が区間 CC' $(2 x+t)$ に生じ，その区間では柱フランジの面外曲 げ変形が許容される ${ }^{3)}$ 。ここで, $t$ は柱フランジに形成 された降伏線 $\mathrm{BB}, \mathrm{B}^{\prime} \mathrm{B}^{\prime}$ の間隔， $x$ は末知数で方る。

iii）柱フランジには降伏線 $\mathrm{AA}, \mathrm{A}^{\prime} \mathrm{A}^{\prime}, \mathrm{BB}, \mathrm{B}^{\prime} \mathrm{B}^{\prime}, \mathrm{AB}$, $\mathrm{A}^{\prime} \mathrm{B}^{\prime}$ が形成される。これら降伏線の単位長さ当たりの 降伏モーメントは（1）式の柱フランジの面外曲げ降伏 モーメント ${ }_{f} M_{p}$ とする。

$$
{ }_{f} M_{p}=\frac{{ }_{c} t_{f}^{2} \cdot{ }_{f} \sigma_{y}}{4} .
$$

ここで, ${ }_{f} \sigma_{y}$ : 柱フランジ素材の降伏点である。

iv）柱フランジと鉛直スチフナの交線には降代線 $\mathrm{AA}^{\prime}$ が形成される。降伏線の単位長さ当たりの降伏E一メン トは (2) 式の ${ }_{s} M_{p}$ とする。 


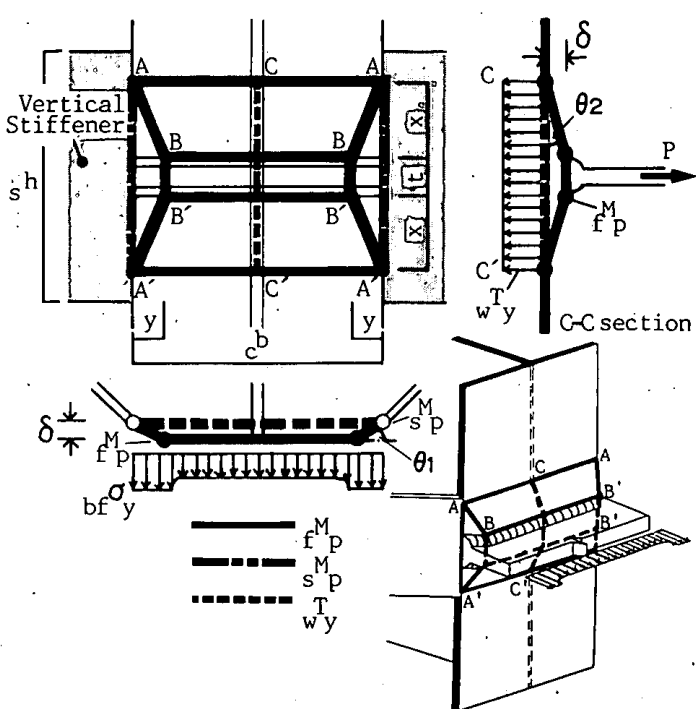

Fig. 9 Yield Line Mechanism in Steel Column for Cruciform Specimen

$$
{ }_{s} M_{p}=\operatorname{MIN}\left\{\frac{c t_{f}^{2} \cdot{ }_{s} \sigma_{y}}{4}, \frac{s t^{2} \cdot{ }_{s} \sigma_{y}}{4}\right\}
$$

ここで, MIN $\}$ |は括弧のうちいずれか小さい方の值, ${ }_{s} \sigma_{y}:$ 鉛直スチフナ素材の降伏点である。

なお，柱フランジの降伏線 $\mathrm{AA}, \mathrm{A}^{\prime} \mathrm{A}^{\prime}$ の間隔が鉛直 スチフナの幅より広い場合は，鉛直スチフナの降伏線は その偪だけ形成されることになる。

はりフランジの作用荷重 $P$ により, 弾性域のはりフ ランジ部分が取り合う柱フランジの $\mathrm{BBB}^{\prime} \mathrm{B}^{\prime}$ 部分に面 外曲げ変形 $\delta$ が生じると仮定すると, 柱フランジの回 転角は降伏線 $\mathrm{AA}^{\prime}, \mathrm{BB}^{\prime}$ に対し $\theta_{1}=\delta / y$, 降伏線 $\mathrm{AA}$, $\mathrm{A}^{\prime} \mathrm{A}^{\prime}, \mathrm{BB}, \mathrm{B}^{\prime} \mathrm{B}^{\prime}$ に対し $\theta_{2}=\delta / x$, 降伏線 $\mathrm{AB}, \mathrm{A}^{\prime} \mathrm{B}^{\prime}$ に対し $\theta_{3}=\delta \sqrt{x^{2}+y^{2}} /(x \cdot y)$ となる。

はりフランジに作用する荷重 $P$ のなす外部仕事 $\left({ }_{b} E_{x}\right)$ は ( 3 ) 式となる。

$$
{ }_{b} E_{x}=\left(P-y \cdot{ }_{b} t_{f} \cdot{ }_{b f} \sigma_{y}\right) y \cdot \theta_{1}
$$

ここで, ${ }_{b} t_{f}:$ はりフランジ厚さ, ${ }_{b} \sigma_{y}:$ はりフランジ素 材の降伏点である。

鉛直スチフナ, 柱フランジおよびウェブのなす内部仕 事 $\left(_{c} E_{i}\right)$ は $(4)$ 式となる。

$$
\begin{aligned}
{ }_{c} E_{i}= & 2_{s} M_{\rho}(2 x+t) \theta_{1}+2_{f} M_{p}\left\{t \cdot \theta_{1}+2\left({ }_{c} b-y\right) \theta_{2}\right. \\
& \left.+2 \sqrt{x^{2}+y^{2}} \theta_{3}\right\}+{ }_{w} T_{y}(x+t) y \cdot \theta_{1} \\
& \quad \text { for }{ }_{s} h \geqq(2 x+t) \\
{ }_{c} E_{i}= & 2{ }_{s} M_{p} \cdot{ }_{s} h \cdot \theta_{1}+2{ }_{s} M_{p}\left\{t \cdot \theta_{1}+2\left({ }_{c} b-y\right) \theta_{2}\right. \\
& \left.+2 \sqrt{x^{2}+y^{2}} \theta_{3}\right\}+{ }_{w} T_{y}(x+t) y \cdot \theta_{1} \\
& \text { for }{ }_{s} h<(2 x+t)
\end{aligned}
$$

ここで, ${ }_{c} b$ : 柱フランジ幅, ${ }_{w} T_{y}={ }_{c} t_{w}{ }_{w} \sigma_{y}:$ 柱ウェブ の単位長さ当たりの引張降伏耐力, ${ }_{c} t_{w}$ : 柱ウェブ厚さ, ${ }_{w} \sigma_{y}:$ 柱ウェブ素材の降伏点である。

接合部の降伏耐力 $\left.{ }_{s} P_{\rho}\right)$ は, (3) 式と（4) 式を等

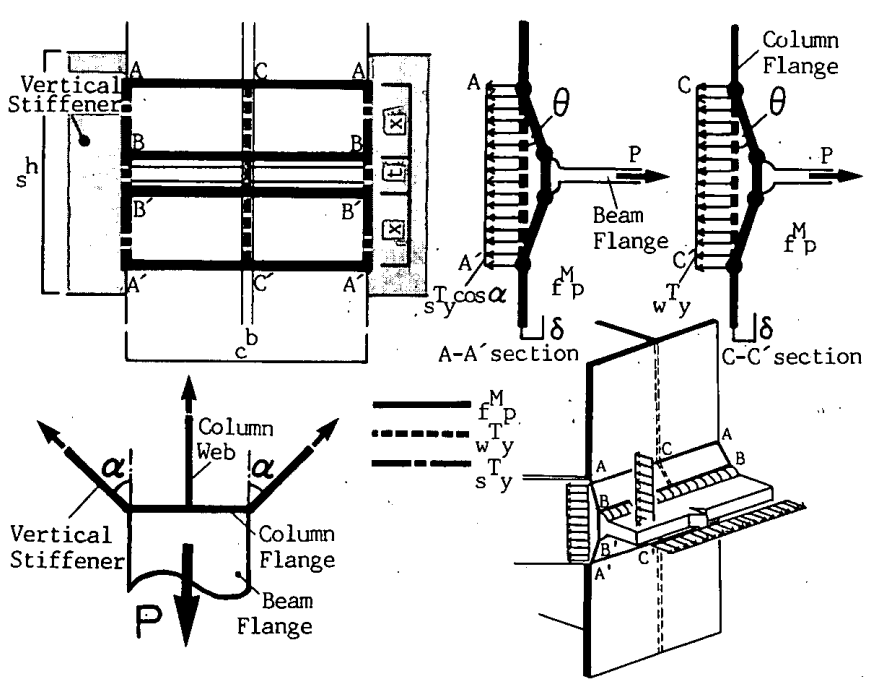

Fig. 10 Yield Line Mechanism in Steel-Concrete or SteelReinforced-Concrete Column for Cruciform Specimen

しいとして求めた $P$ が最小となるように未知数 $x, y$ を 決定すれば得られ，（5）式となる。

$$
\begin{aligned}
{ }_{s} P_{p}= & 2{ }_{f} M_{\rho} \cdot{ }_{c} b(4 x+t) \frac{1}{x^{2}}+\frac{1}{2} \cdot{ }_{w} T_{y} \cdot t \\
& +\frac{4\left({ }_{s} M_{\rho}+{ }_{f} M_{p}\right) x^{2}}{4_{f} M_{\rho} \cdot{ }_{c} b-{ }_{w} T_{y} \cdot x^{2}} \cdot{ }_{b} t_{f} \cdot{ }_{b f} \sigma_{y} \\
& \quad \text { for }{ }_{s} h \geqq(2 x+t) \\
{ }_{s} P_{p}= & \left.2{ }_{c} b{ }_{s} M_{\rho} \cdot{ }_{s} h+{ }_{f} M_{p}(4 x+t)\right\} \frac{1}{x^{2}} \\
& +\frac{1}{2}\left(t-\frac{{ }_{s} M_{\rho}}{{ }_{f} M_{p}}{ }_{s} h\right)_{w} T_{y} \\
& +\frac{4{ }_{s} M_{\rho}: x^{2}}{4_{f} M_{\rho} \cdot{ }_{c} b-{ }_{w} T_{y} \cdot x^{2}} \cdot{ }_{o} t_{f} \cdot{ }_{b s} \sigma_{y} \\
& \text { for }{ }_{s} h<(2 x+t)
\end{aligned}
$$

ただし，（5）式の $x$ は（6）式の解である。

$$
\begin{aligned}
& \left.2_{w} T_{y}^{2} \cdot x^{5}+{ }_{w} T_{y}^{2} \cdot t-8\left({ }_{s} M_{p}+{ }_{f} M_{p}\right)_{b} t_{f} \cdot{ }_{b f} \sigma_{y}\right\} x^{4} \\
& -16{ }_{f} M_{p} \cdot{ }_{c} b \cdot{ }_{w} T_{y} \cdot x^{3}-8{ }_{f} M_{p} \cdot{ }_{c} b \cdot{ }_{w} T_{y} \cdot t \cdot x^{2} \\
& +32{ }_{f} M_{\rho}^{2}{ }_{c} b^{2} \cdot x+16{ }_{f} M_{p}^{2} \cdot{ }_{c} b^{2} \cdot t=0 \\
& \text { for }{ }_{s} h \geqq(2 x+t) \\
& { }_{2} M_{p} \cdot{ }_{w} T_{y}^{2} \cdot x^{5}+\left({ }_{s} M_{p} \cdot{ }_{s} h+{ }_{f} M_{p} \cdot t\right)_{w} T_{y}^{2} \\
& -8{ }_{f} M_{p}^{2} \cdot{ }_{b} t_{f} \cdot{ }_{b f} \sigma_{y} \mid x^{4}-16_{f} M_{\rho}^{2} \cdot{ }_{c} b \cdot{ }_{w} T_{y} \cdot x^{3} \\
& -8 M_{p} \cdot{ }_{c} b \cdot{ }_{w} T_{y}\left({ }_{s} M_{p} \cdot{ }_{s} h+{ }_{j} M_{p} \cdot t\right) x^{2} \\
& +32{ }_{s} M_{\rho}^{3} \cdot{ }_{c} b^{2} \cdot x+16{ }_{f} M_{\rho}^{2} \cdot{ }_{c} b^{2}\left({ }_{s} M_{\rho} \cdot{ }_{s} h+{ }_{f} M_{\rho} \cdot t\right)=0 \\
& \text { for }{ }_{s} h<(2 x+t)
\end{aligned}
$$

ここで, 柱鉄骨フランジの降伏線 $\mathrm{BB}, \mathrm{B}^{\prime} \mathrm{B}^{\prime}$ の間隔 $t$ として, スチフナ補強のないH断面柱一はり引張側フ ランジ接合部に関するWardenier J. の研究を参考にし て（7）式を用いる ${ }^{3 !} 。$

$$
t={ }_{r} t+{ }_{c} t_{s}
$$


ここで, ${ }_{r} t:$ 補強盛を含むはりフランジの溶接寸法で ある。

接合部の最大耐力 $\left({ }_{s} P_{m}\right)$ の評価に際しては, 全塑性耐 力の評価式（5）および（6）式における素材の降伏点 の代わりに引張強さを用いることとする。

（2） 柱：鉄骨コンクリート構造（SC）

接合部の全塑性耐力を，試験体 C-10e のひずみ分布 を参照して, 図一10 の崩壊機構を仮定して解析する。 すなわち，解析に用いた主な仮定は以下のとおりである。

i）鉛直スチフナおよび柱鉄骨ウェブは応力集中によ り引張降伏域が区間 $\mathrm{AA}^{\prime}$ および CC' (ともに $2 x+t$ ) に生じ，その区間では柱鉄骨フランジの面外変形が許容 される。なお，柱鉄骨フランジの降伏線 $\mathrm{AA}, \mathrm{A}^{\prime} \mathrm{A}^{\prime}$ の 間隔が鉛直スチフナの幅より広い場合は，鉛直スチフナ の引張降伏域は鉛直スチフナ幅だけとなる。

ii）柱鉄骨フランジには降伏線 $\mathrm{AA}, \mathrm{A}^{\prime} \mathrm{A}^{\prime}, \mathrm{BB}$, $\mathrm{B}^{\prime} \mathrm{B}^{\prime}$ が形成される。これら降伏線の単位長さ当たりの 降伏モーメントは $(1)$ 式に示す ${ }_{s} M_{p}$ とする。

はりフランジの作用荷重 $P$ のなす外部仕事 $\left.{ }_{b} E_{x}\right)$ は, 柱鉄骨フランジに形成される降伏線の回転角を $\theta$ とす れば,（8）式となる。

$$
{ }_{0} E_{x}=P \cdot x \cdot \theta \cdot \cdots
$$

鉛直スチフナ, 柱鉄骨フランジおよびウェブのなす内 部仕事 $\left.{ }_{c} E_{l}\right)$ は $(9)$ 式となる。

$$
\begin{aligned}
{ }_{c} E_{i}= & 2{ }_{s} T_{y}(x+t) x \cdot \theta \cdot \cos \alpha \\
& +4_{s} M_{p} \cdot{ }_{c} b \cdot \theta+{ }_{w} T_{y}(x+t) x \cdot \theta \\
& \quad \text { for }{ }_{s} h \geqq(2 x+t) \\
{ }_{c} E_{i}= & 2{ }_{s} T_{y} l_{s} h \cdot x-\left({ }_{s} h-t\right)^{2} / 4 \mid \theta \cdot \cos \alpha \\
& +4_{s} M_{p} \cdot{ }_{c} b \cdot \theta+{ }_{w} T_{y}(x+t) x \cdot \theta \\
& \quad \text { for }{ }_{s} h<(2 x+t)
\end{aligned}
$$

ここで, ${ }_{s} T_{y}={ }_{s} t \cdot{ }_{s} \sigma_{y}$ ：鉛直スチフナの単位長さ当たり の引張降伏耐力, $\alpha$ : 鉛直スチフナの傾斜角で本実験で は $a=\pi / 4$ である（図一10参照）。

接合部の全塑性耐力 $\left(s c P_{p}\right)$ は $(8),(9)$ 式が等しい として求めた $P$ が最小となるように末知数 $x$ を決定す れば得られ，(10) 式となる。

$$
\begin{aligned}
& { }_{\mathrm{sc}} P_{p}=4 \sqrt{{ }_{s} M_{p}{ }^{\circ} b\left(2_{s} T_{y} \cos \alpha+{ }_{w} T_{y}\right)} \\
& +\left(2_{s} T_{y} \cos \alpha+{ }_{w} T_{y}\right) t \\
& \text { for }{ }_{s} h \geqq 4 \sqrt{\frac{{ }_{s} M_{p}{ }_{c} b}{2_{s} T_{y} \cos \alpha+{ }_{w} T_{y}}}+t \\
& { }_{s c} P_{p}=4 \sqrt{\left.\mid{ }_{s} M_{p} \cdot{ }_{c} b-{ }_{s} T_{y} \cos \alpha(s h-t)^{2} / 8\right\}_{w} T_{y}} \\
& +2{ }_{s} T_{y} \cos \alpha \cdot{ }_{s} h+{ }_{w} T_{y} \cdot t \\
& \text { for }{ }_{s} h<4 \sqrt{\frac{{ }^{\prime} M_{p^{*}}{ }^{b} b}{2_{s} T_{y} \cos \alpha+{ }_{w} T_{y}}}+t
\end{aligned}
$$

接合部の最大耐力 $\left({ }_{\mathrm{sc}} P_{m}\right)$ の評価に際しては, 全塑性 耐力の評価式（10）式における素材の降伏点の代わりに
引張強さを用いることとする。
（3） 柱：鉄骨鉄筋コンクリート構造 (SRC)

$\mathrm{SRC}$ 柱の被覆コンクリート部分は, 柱の鉄骨部分に 崩壊機構が形成され，柱鉄骨フランジの面外曲げ変形が 許容されると同時に被覆コンクリートにコーン状ひび割 れが発生したと考えられる（図一8参照）。そこで，接 合部の全塑性耐力 $\left(\mathrm{SRC}_{\mathrm{s}} P_{p}\right)$ は柱鉄骨部分に柱が $\mathrm{SC}$ の場 合と同様に図一 10 に仮定する崩壊機構が形成され，被 覆コンクリート部分に図一11 に仮定するコーン状ひび 割れが形成された状態であると考える。

被覆コンクリート部分は接合部の全塑性耐力時には, 検討の余地は残るが，コーン状破壊に対する短期許容耐 力を負担すると仮定する ${ }^{5), 6)}$ 。ここで, 本実験においては， 帯筋は仮定した被覆コンクリートのコーン状ひび割れ面 でコンクリートのせん断変形をその引張抵抗力で拘束す るように配置されていないこと7，また，複合構造の接 合部耐力に関する既往の研究によれば被覆コンクリート 部分の負担耐力はコンクリートのコーン状破壊耐力だけ を考慮すればよく，帯筋などの補強鉄筋の効果は無視で きるという報告があること帛などより，本解析において も帯筋の接合部耐力に及ぼす効果を無視することとす る。

はりフランジが取り合う側の被覆コンクリート部分に 図一11 に示すコーン状ひび割れ面を仮定すれば，接合 部の全塑性耐力時に $\mathrm{SRC}$ 柱のなす内部仕事は（9）式 に $\left\{2\left(2 x+t+{ }_{c} b\right) d+\pi d^{2} \mid 0.6 \sqrt{F_{c}} \cdot \delta\right.$ (ここで, $F_{c}:$ コ ンクリートの圧縮強度 $\left(\mathrm{kgf} / \mathrm{cm}^{2}\right), d$ : 被覆コンクリー トの被り厚さ）を加えれば良い。

接合部の全塑性耐力 $\left(\mathrm{sac} P_{p}\right)$ は, 柱が $\mathrm{SC}$ の場合と同 じようにして求めることができ，(11）式となる。

$$
\begin{aligned}
& { }_{\mathrm{SRC}} P_{p}=4 \sqrt{{ } M_{p^{*} \mathrm{c}} b\left(2_{s} T_{y} \cos \alpha+{ }_{w} T_{y}+2.4 d \sqrt{F_{c}}\right)} \\
& +\left(2 T_{s} \cos \alpha+{ }_{w} T_{y}\right) t+\left\{2\left(t+{ }_{c} b\right) d+\pi d^{2} \mid 0.6 \sqrt{F_{c}}\right. \\
& \text { for }{ }_{s} h \geqq 4 \sqrt{\frac{{ }_{j} M_{p^{\circ}} b}{2_{s} T_{y} \cos a+{ }_{w} T_{y}+2.4 d \sqrt{F_{c}}}}+t \\
& { }_{\mathrm{SRC}} P_{p}=4 \sqrt{\left.\mid M_{p} \cdot{ }_{c} b-{ }_{s} T_{y} \cos \alpha\left({ }_{s} h-t\right)^{2} / 8\right\}\left({ }_{s} T_{y}+2.4 d \sqrt{F_{c}}\right)} \\
& \}
\end{aligned}
$$

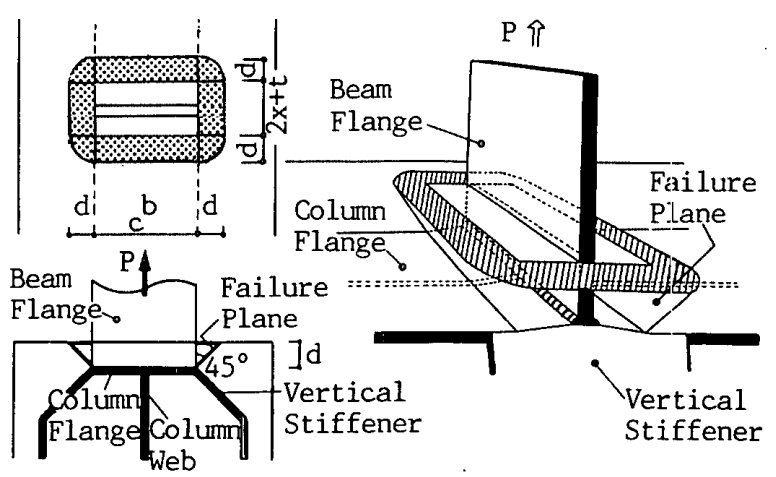

Fig. 11 Failure Plane of Punching Shear in Concrete 
$+2 T_{s} \cos \alpha \cdot{ }_{s} h+{ }_{w} T_{y} \cdot t+\left\{2\left(t+{ }_{c} b\right) d+\pi d^{2}\right\} 0.6 \sqrt{F_{c}}$

$$
\text { for }{ }_{s} h<4 \sqrt{\frac{{ }_{s} M_{\rho}{ }_{c} b}{2_{s} T_{y} \cos \alpha+{ }_{w} T_{y}+2.4 d \sqrt{F_{c}}}}+t
$$

接合部の最大耐力 $\left({ }_{\mathrm{sRC}} P_{m}\right)$ の評価に際しては，全塑性 耐力の評価式（11）式における鋼材の降伏点の代わりに 引張強さを, 被覆コンクリート部分のコーン状破壊に対 する短期許容応力度 $0.6 \sqrt{F_{c}}$ の代わりに破壊応力度 $\sqrt{F_{c}}$ を用いることにする。

本研究では図一 2 に示す柱が SRC と SC の接合部の $P-\Delta$ 曲線を比較すると, 接合部の局部変形量 $(\Delta)$ が大 きくなった以後においても両者の耐力差に変化がほとん ビ生じていないことを考慮して; 被覆コンクリート部分 は接合部の最大耐力時までそのコーン状破壊耐力を保持 していると仮定している。しかし，この仮定の妥当性は， コーン状破壊を起こす被覆コンクリート部分のせん断変 形能力 ${ }^{6}$ の観点からも, 今後さらに検討を進める必要が ある。

2.4 解析值と実験值の対応

(1) 柱：鉄骨構造 '(S)

試験体 N-10e の解析值を表一4に示す。全塑性耐力 の㬰験值と解析值の比は ${ }_{e} P_{\rho} / \mathrm{s} P_{p}=0.97$ と両者の対応 は良好である。また，図一5の柱フランジのひずみ分布 およびはりフランジのひずみ分布に解析上の $x$ および $y$ 寸法を示したが，これらひずみ分布の実験結果は解析 モデルと良い対応を示している。また, 本試験体は解析 では $2 x+t>{ }_{s} h$ となるが，これは鉛直スチフナが全塑 性耐力時には全面的に面外曲げ降伏していることと対応 している。しかし，最大耐力の解析値は実験值を若干過 大評価している。

（2）柱：鉄骨コンクリート構造 (SC)

各試験体の解析值を表一4 に示す。全塑性酎力の実験 値之解析値の比は ${ }_{e} P_{\rho} / \mathrm{sc} P_{\rho}$ は $1.15 \sim 1.28$ (平均値 1.21) となり，解析值は実験值を若干過小評価している。ここ で，各試験体の ${ }_{\mathrm{sc}} P_{\rho}$ を図一 2 の $P-\Delta$ 曲線上に○印で示 すが， ${ }_{s c} P_{p}$ は各試験体とも，P- $\Delta$ 曲線上で剛性が低下

Table 4 Analytical Results for Cruciform Specimens

\begin{tabular}{|c|c|c|c|c|c|c|}
\hline & \multicolumn{3}{|c|}{ General Yield Strength } & \multicolumn{2}{|c|}{ Maximum Strength } \\
\hline & & $P_{p}[t f]$ & {$\left[\mathrm{cm}^{\mathrm{t}}\right][\mathrm{cm}]$ CASE } & $e^{P} p^{P} p$ & $\mathrm{P}_{\mathrm{m}}[t f]$ & $\mathrm{e}^{\mathrm{P}_{\mathrm{m}} / \mathrm{P}_{\mathrm{m}}}$ \\
\hline & $\mathrm{N}-10 \mathrm{e}$ & 49.90 & $3.66 \quad 3.58$ & 0.97 & 80.09 & 0.87 \\
\hline$\dot{\omega}$ & $\begin{array}{l}\mathrm{C}-10 \mathrm{e} \\
\mathrm{c}-10 \mathrm{~s} \\
\mathrm{C}-10 \mathrm{f} \\
\mathrm{C}-05 \mathrm{e} \\
\mathrm{c}-20 \mathrm{e}\end{array}$ & $\begin{array}{l}52.00 \\
69.68 \\
67.07 \\
43.12 \\
51.37\end{array}$ & $\begin{array}{ll}3.33 & 3.24 \\
3.35 & 2.24 \\
4.44 & 4.41 \\
3.59 & 4.18 \\
3.28 & 2.69\end{array}$ & $\begin{array}{l}1.28 \\
1.15 \\
1.22 \\
1.15 \\
1.23\end{array}$ & $\begin{array}{r}83.02 \\
112.82 \\
107.39 \\
68.83 \\
82.10\end{array}$ & $\begin{array}{l}1.14 \\
0.94 \\
1.13 \\
1.01 \\
1.07\end{array}$ \\
\hline শ্口 & $\begin{array}{l}R-10 \mathrm{e} \\
\mathrm{R}-10 \mathrm{~s} \\
\mathrm{R}-10 \mathrm{f} \\
\mathrm{R}-05 \mathrm{e} \\
\mathrm{R}-20 \mathrm{e}\end{array}$ & $\begin{array}{l}59.18 \\
78.84 \\
78.76 \\
48.46 \\
65.69 \\
\end{array}$ & $\begin{array}{ll}3.40 & 3.07 \\
3.66 & 2.33 \\
4.15 & 3.74 \\
3.10 & 3.92 \\
3.88 & 2.63 \\
\end{array}$ & $\begin{array}{l}1.20 \\
1.09 \\
1.07 \\
1.11 \\
1.26\end{array}$ & $\begin{array}{r}94.88 \\
125.70 \\
119.59 \\
77.77 \\
100.25\end{array}$ & $\begin{array}{l}1.08 \\
1.05 \\
1.09 \\
1.08 \\
1.21\end{array}$ \\
\hline
\end{tabular}

する時の荷重とほぼ対応している。また, 解析值は鉛直 スチフナの幅および厚さ，柱鉄骨フランジ厚さ等の実験 因子の影響を比較的良くとらえているといえる。

また，図一6の鉛直スチフナおよび柱鉄骨フランジの ひずみ分布に各試験体の解析上の $x$ 寸法を示したが, これらひずみ分布の実験結果は解析モデルと比較的良い 対応を示している。

試験体 C-05e，C-10 e および C-20eについて鉛直 スチフナ幅と解析上の鉛直スチフナの引張降伏域の大き さの比 ${ }_{s} h /(2 x+t)$ を求めるとそれぞれ $0.33,0.82$, 1.86 となる。これより ${ }_{s} h /(2 x+t)<1.0$ の範囲で ${ }_{s} h$ を 大きくすれば全塑性耐力は上昇するが, $s h /(2 x+t) \geqq$ 1.0 の範囲では ${ }_{s} h$ を大きくしても全塑性耐力の上昇は 期待できないことが予测される。

各試験体の最大耐力の実験值と解析値の比は $P_{m} /$ ${ }_{\mathrm{sc}} P_{\mathrm{m}}$ は 0.94〜1.14（平均值 1.06）となり，両者の対応 は比較的良好である。しかし，鉛直スチフフ厚さが柱鉄 骨フランジ厚さより厚い C-10 s では解析值は実験值を 若干過大評価している。鉛直スチフナ厚さの適用範囲に ついては今後の検討課題である。

(3) ·柱：鉄骨鉄筋コンクリート構造 (SRC)

各試験体の解析值を表一 4 に示す。実験値と解析値の 比は全塑性耐力で ${ }_{e} P_{p} / \mathrm{SRC}_{p}=1.07 \sim 1.26$ (平均值 1.15 ), 最大耐力で ${ }_{e} P_{m} / \mathrm{sRc} P_{m}=1.05 \sim 1.21$ (平均値 1.10)となり, 両者とも柱が SC の場合と同等の值となっ ている。したがって, 被覆コンクリート部分の負担耐力 の評価はほぼ妥当なものと考えられる。

\section{3. 部分架構実験による検討}

\section{1 試験体および実験結果}

骨組架構の柱はり接合部の応力状態は，部分モデル試 験のそれと以下に示す点で相違し, 複雑な応力状態下に ある。

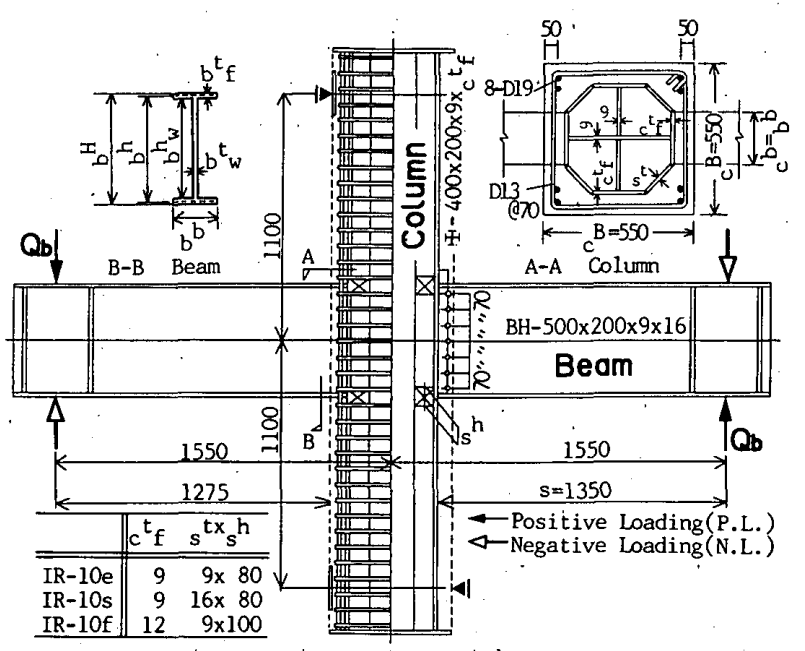

Fig. 12 Geometry of Connection Assemblage Specimens 
i ）柱の作用応力により，柱フランジには軸方向応力， 柱ウェブには軸方向応力およびせん断応力が作用する。 ii）接合部パネル部の柱ウェブには高いせん断応力が作 用する。

したがって，部分モデル試験により得られた接合部の 耐力評価方法が骨組架構の柱はり接合部に適用できるか を実験的に検討する。

試験体は柱が SRC，はりがSの十字形・柱はり接合 部試験体で，その形状を図一12 に示す。柱の鉄骨要素

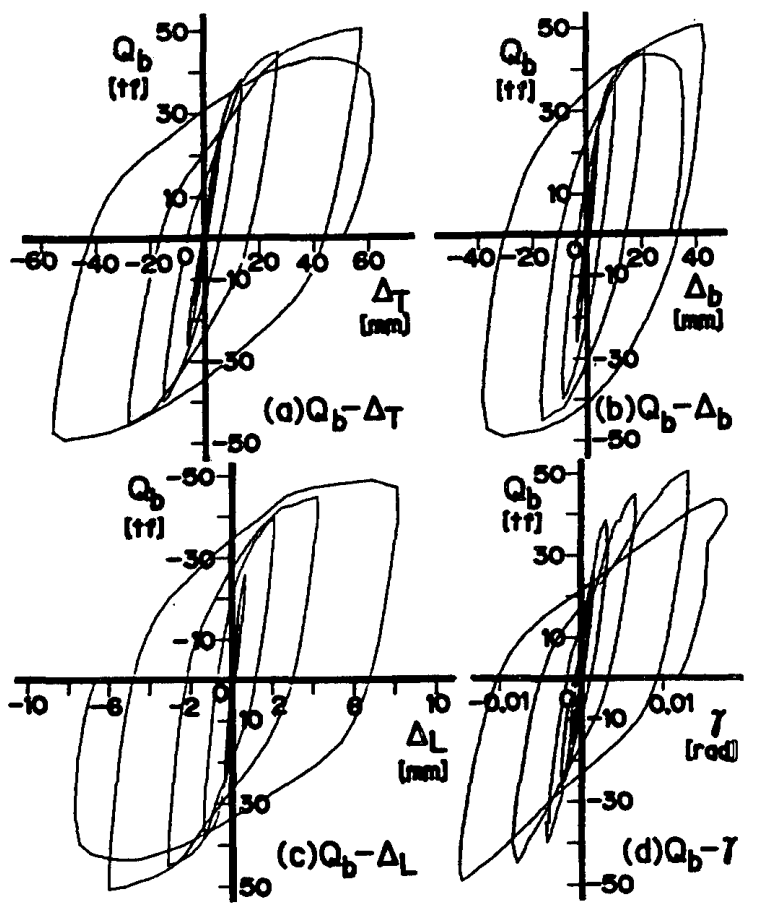

Fig. 13 Hysteretic Curves of IR-10e
とはりフランジの接合詳細は, 試験体 IR-10e, IR$10 \mathrm{~s}$ および IR-10 f は部分モデル試験体の R-10 e, R$10 \mathrm{~s}$ および R-10 f にそれぞれ対応する。使用材料は部 分モデル試験体と共通とし，それらの機械的性質を表一 2 に示す。

載荷ははり両端にアクチュエータにより逆対称の正負 漸増絽返し載荷 $Q_{b}$ を加えた。試験体 IR-10e について 荷重 $\left(Q_{b}\right)$ と全体変形 $\left(\Delta_{T}\right)$ の関係 $\left(Q_{b}-\Delta_{T}\right.$ 曲線 $)$, はりの 変形 $\left(\Delta_{b}\right)$ の関係 $\left(Q_{b}-\Delta_{b}\right.$ 曲線 $), S R C$ 柱とはりフラン ジ接合部の局部変形 $\left(\Delta_{L}\right)$ の関係 $\left(Q_{b}-\Delta_{L}\right.$ 曲線 $)$ ，および 接合部パネルのせん断変形角 $(\gamma)$ の関係 $\left(Q_{b}-\gamma\right.$ 曲線 $)$ を図一13に，また，最大耐力時における柱のコンクリー トのひび割れ状況を図一14に示す。なお，各詿験体と も $Q_{b}-\Delta_{L}$ 曲線は紡鍾形の安定した履歴特性を示してい

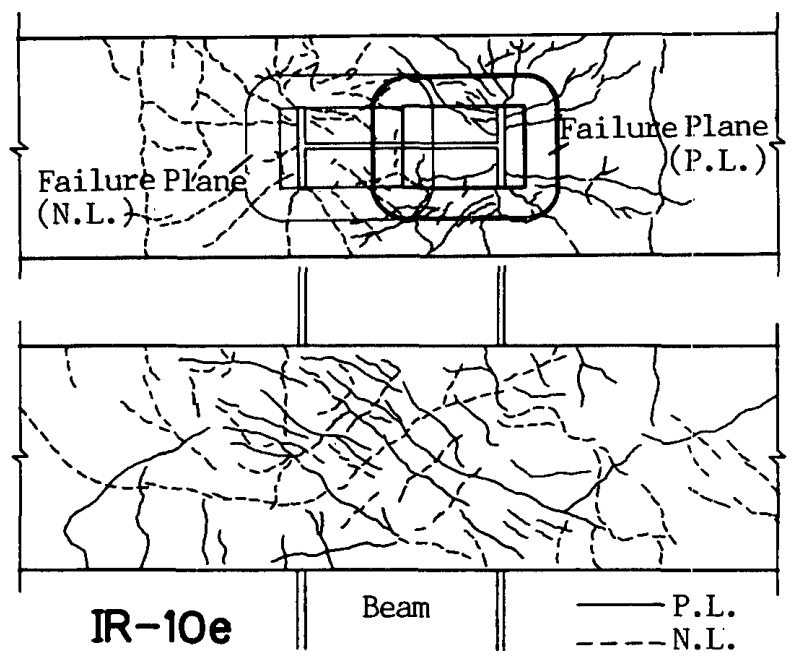

Fig. 14 Crack Pattern in Concrete of IR-10 e

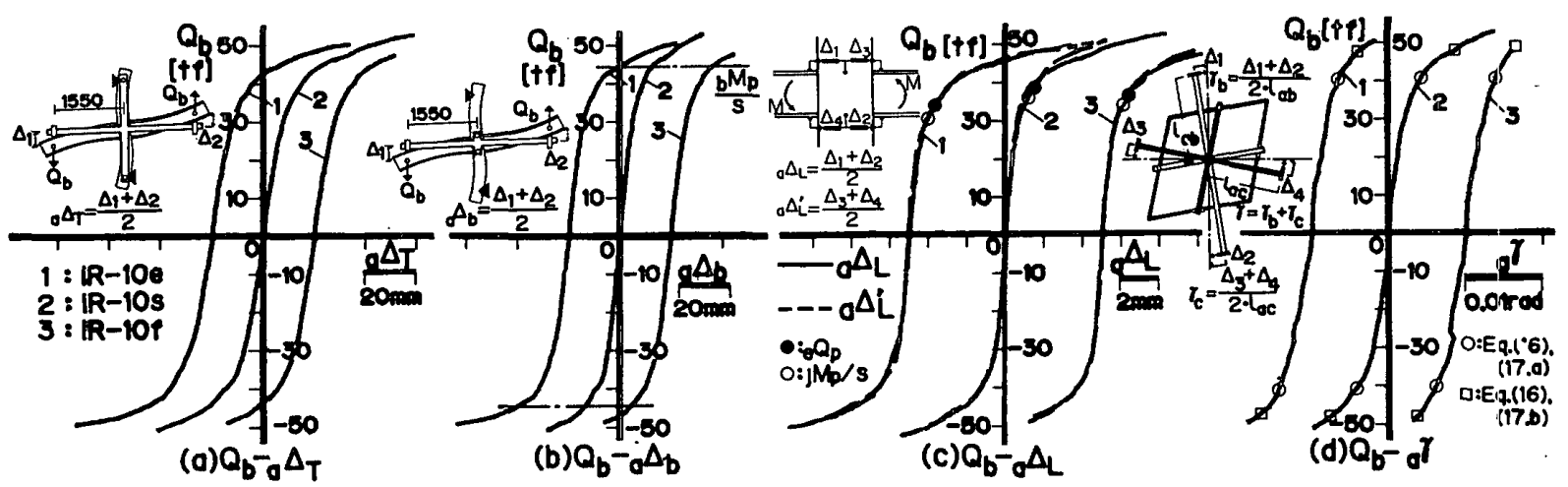

Fig. 15 Synthetic Curves of Connection Assemblage Specimens

Table 5 Test Results in Comparison with Estimated Strength for Connection Assemblage Specimens

\begin{tabular}{|c|c|c|c|c|c|c|c|c|c|c|c|}
\hline & \multicolumn{7}{|c|}{ Beam End Connection } & \multirow{2}{*}{\multicolumn{2}{|c|}{$\frac{\begin{array}{c}\text { Connection } \\
\text { Panel }\end{array}}{\mathrm{p}_{\mathrm{AS}}[\mathrm{tf}]}$}} & \multirow{3}{*}{\begin{tabular}{|l} 
Beam \\
$b^{Q} p$ \\
{$[t f]$} \\
\end{tabular}} & \multirow{3}{*}{ 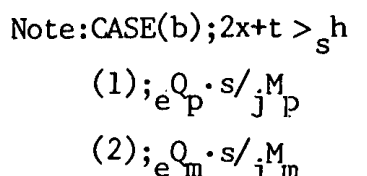 } \\
\hline & \multirow{2}{*}{$\begin{array}{r}e^{Q} p \\
{[t f]}\end{array}$} & \multirow{2}{*}{\multicolumn{2}{|c|}{ 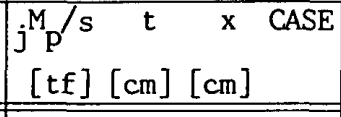 }} & \multirow{2}{*}{ (1) } & \multirow{2}{*}{$\begin{array}{r}e^{O} m \\
{[t f]}\end{array}$} & \multirow{2}{*}{$\begin{array}{r}j^{M} / \mathrm{m} \\
{[\mathrm{tf}]}\end{array}$} & \multirow{2}{*}{ (2) } & & & & \\
\hline & & & & & & & & (3) & (4) & & \\
\hline IR-10e & $\begin{array}{l}34.3 \\
32.7 \\
\end{array}$ & $31.18 \quad 4.06$ & 3.36 (b) & $\begin{array}{l}1.10 \\
1.05 \\
\end{array}$ & $\begin{array}{c}50.65 \\
---\end{array}$ & 47.39 & $\begin{array}{c}1.07 \\
-- \\
\end{array}$ & $\begin{array}{l}173.87 \\
(41.19) \\
\end{array}$ & $\begin{array}{l}200.90 \\
(47.59)\end{array}$ & 42.30 & $(3){ }_{s} Q_{p}=E q \cdot(17 \cdot a)$ \\
\hline IR-10s & $\begin{array}{l}39.3 \\
38.0 \\
\end{array}$ & 37.473 .98 & $2.71 \quad(b)$ & $\begin{array}{l}.05 \\
1.01 \\
\end{array}$ & $\begin{array}{c}52.95 \\
---\end{array}$ & 59.55 & $\begin{array}{c}0.89 \\
-- \\
\end{array}$ & $\begin{array}{l}174.46 \\
(41.32)\end{array}$ & $\begin{array}{l}201.31 \\
(47.68)\end{array}$ & 41.48 & $(4) ;{ }_{s} Q_{p}=E q \cdot(17 . b)$ \\
\hline IR-10f & $\begin{array}{l}37.3 \\
38.7 \\
\end{array}$ & 34.694 .42 & 4.19 & \begin{tabular}{|l|}
1.08 \\
1.12 \\
\end{tabular} & $\begin{array}{c}47.55 \\
---\end{array}$ & 52.82 & $\begin{array}{c}0.90 \\
--\end{array}$ & $\begin{array}{l}173.43 \\
(41.05) \\
\end{array}$ & $\begin{array}{l}208.76 \\
(49.41) \\
\end{array}$ & 41.19 & \\
\hline
\end{tabular}


る。また，正負漸増繰返し載荷実験により得られた履歴 曲線から試験体の各種耐力および変形性状を大づかみす ることを目的として, 累加経験則9 に基づいて求めた, 各試験体の荷重 $\left(Q_{b}\right)$ と累積変形 $\left({ }_{a} \Delta_{T},{ }_{a} \Delta_{b},{ }_{a} \Delta_{L},{ }_{a} \gamma\right)$ の 関係を図一15に示す。

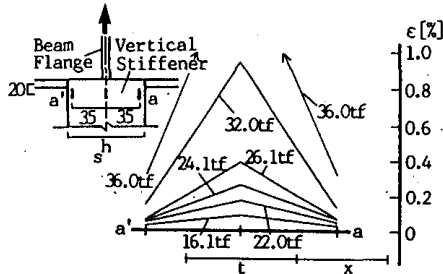

(a) Vertical Stiffener

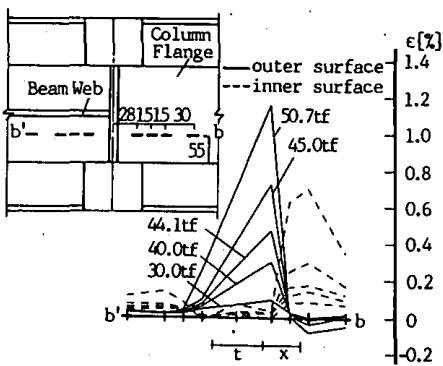

(b) Column Flange

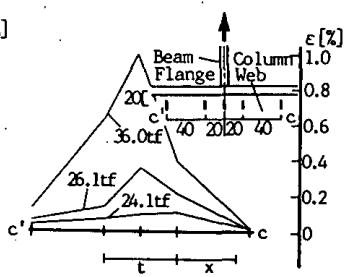

(c) Column Web
Fig. 16 Strain Distributions in IR-10e
$\mathrm{SRC}$ 柱とはり引張側フランジ接合部の全塑性耐力 $\left(Q_{p}\right)$ を図一15(c) の $Q_{b}{ }^{-}{ }_{a} \Delta_{L}$ 曲線より General Yield Point 法により求めた結果を表一5に示す。

試験体の最大耐力 $\left(e Q_{m}\right)$ を表一 5 に示す。試験体 IR$10 \mathrm{e}$ および IR-10 f は接合部の局部破壊で, IR-10 s は はりウェブのせん断座屈により最大耐力が決定してい る。なお, IR-10e で亀裂 CW, CF, CD が, IR-10 f では亀裂 CW が観察された（図一4 参照)。

なお，IR-10fでは，柱鉄骨フランジとウェブの溶接 がすみ肉溶接（のど厚 $4.0 \mathrm{~mm}$ ）となっていたため, 亀 裂 $\mathrm{CW}$ は溶接部に生じている。そこで，試験体の残材 より十字すみ肉溶接試験体を作成し, 単調引張載荷実験 を行ったところ，破壊は柱ウェブ母材に生じた。両者で 破壊位置が相違している点については今後の検討課題で ある。

試験体 IR-10e の各部にてん付したひずみゲージの荷 重一累積ひずみ関係を用いて求めた挙動を図一16に示 す。

\section{2 実験結果の考察}

（1）はり端接合部の全塑性耐力

はり端接合部の全塑性耐力を，接合部に図一17に示 す崩壊機構が形成されると仮定して，降伏線理論を用い

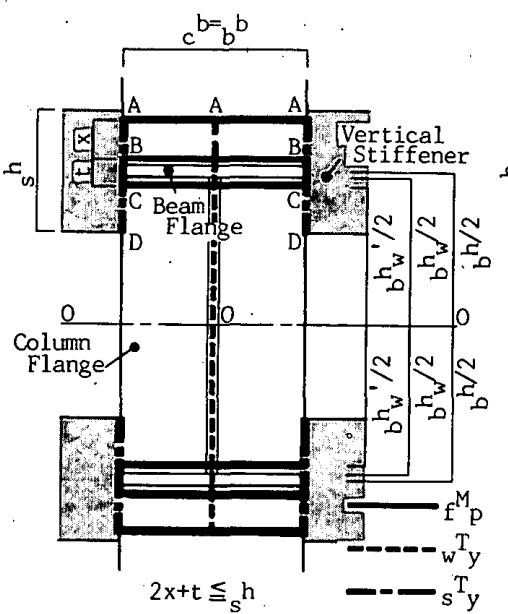

(a) Yield Line Mechanism in Steel Column

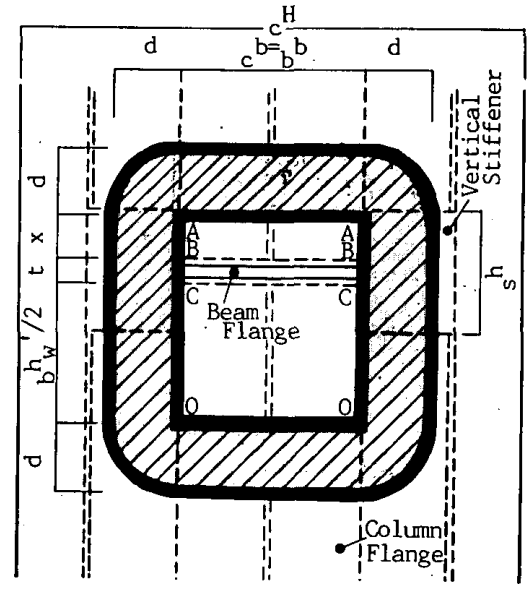

(c) Failure Plane of Punching Shear in Concrete

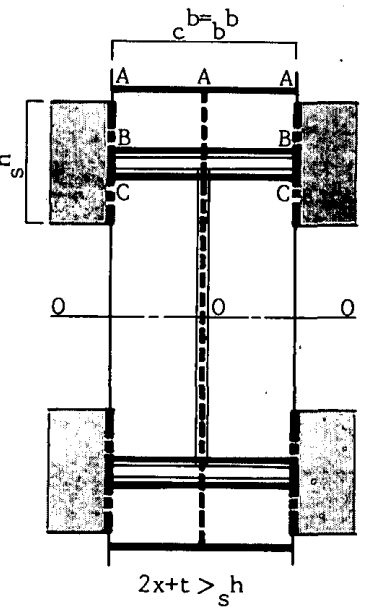
.

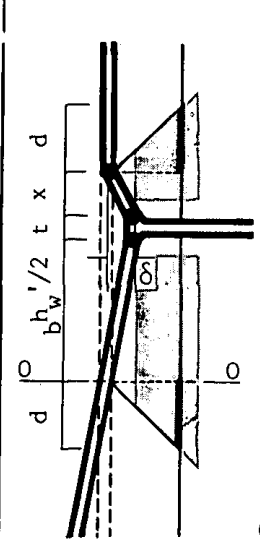

Fig. 17 Yield Line Mechanism

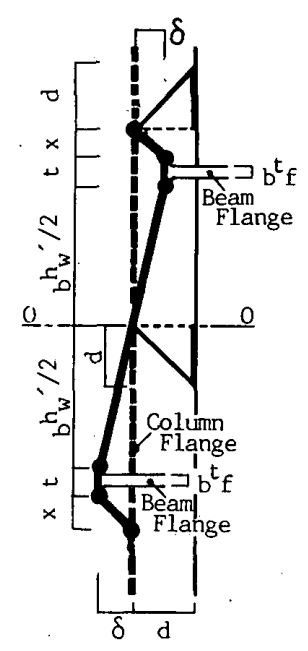

(b) Plastic Deformation of Beam End 
て解析する。

図一17に仮定した崩壊機構は， $Q_{b}{ }^{-}{ }_{a} \Delta_{L}$ 曲線が図一15

(c) に示すとおり, 接合部の全塑性耐力まで, はりフラ ンジの引張側と王縮側で大きな差異が認められないこと を考慮して，はりウェブ中心 00 に対して逆対称と仮定 した。以下に, 接合部に仮定した崩壊機構の概要をはり 引張側（はりウェブ中心 00 より上部）に着目して示す。 i ）柱鉄骨ウェブおよび鉛直スチフナは引張降伏域が区 間 $\mathrm{AO}$ および $\mathrm{AD}$ にそれぞれ生じ，柱鉄骨フランジの 面外変形が許容される（図一17(a) 参照)。ここで, 柱 鉄骨フランジの降伏線 $\mathrm{AA}$ が鉛直スチフナの外側にあ る場合は, 鉛直スチフナの降伏域は鉛直スチフナ幅だけ となる。

ii）柱鉄骨フランジには降伏線 AA，BB，CC が形成 される(図一17(a) 参照)。

iii）はり引張側フランジが取り合う側の被覆コンクリー 卜部分は図一17(c) に仮定するコーン状のせん断変形を 起こし，そのせん断耐力はコーン状破壊に対する短期許 容耐力と仮定する。

iv）上記 i.〜iii. により，はり端接合部に崩壊機構が 形成され，はり端接合部は図一17(b) に示す変形挙動 を示すものとする。

本実験では, SRC 柱とはりフランジ接合部の全塑性 耐力が，表一 5 に示すとおり，はりの全塑性耐力 $\left({ }_{b} Q_{p}\right)$ 以下であることを考慮して, はりの断面内の忘力分布を 図一17(d) のとおり仮定する。

以上の仮定により，はり引張側のなす外部仕事 ${ }_{。} E_{x}$ は（12）式となる。

$$
{ }_{b} E_{x}=\left\{{ }_{b} b \cdot{ }_{b} t_{f}+\frac{{ }_{b} t_{w}}{4_{b} h_{w}}\left({ }_{o} h_{w}^{2}-\frac{1}{3}{ }_{b} h_{w}^{\prime 2}\right)\right\}_{s} \sigma \cdot \delta \cdots \cdots(12)
$$

ここで, ${ }_{b} b$ : はりフランジ幅（本実験の場合 ${ }_{c} b$ に等し い), ${ }_{0} t_{w}$ :はりウェブ厚さ, ${ }_{b} h_{w}={ }_{b} H-2{ }_{b} t_{s}:$ はりウェ ブせい, ${ }_{b} h_{w}^{\prime}={ }_{b} H-\left({ }_{b} t_{f}+t\right),{ }_{b} H ：$ はりせい, ${ }_{s} \sigma:$ はり フランジの平均応力度である。

柱の内部仕事 ${ }_{c} E_{\imath}$ は $2 x+t<{ }_{s} h$ の場合, (13) 式とな る。

$$
\begin{aligned}
{ }_{c} E_{t}= & {\left[{ }_{s} T_{y}\left\{x+2 t+\left({ }_{s} h-t\right) \frac{{ }_{b} h_{w}^{\prime}-\left({ }_{s} h-t\right) / 2}{{ }_{b} h_{w}^{\prime}}\right\} \cos \alpha\right.} \\
& +2{ }_{s} M_{\rho} \cdot{ }_{c} b\left(\frac{1}{x}+\frac{1}{{ }_{b} h_{w}^{\prime}}\right)+{ }_{w} T_{y}\left(\frac{x}{2}+t+\frac{{ }_{b} h_{w}^{\prime}}{4}\right) \\
& \left.+\left\{2\left(x+t+\frac{{ }_{b} h_{w}^{\prime}}{2}+{ }_{c} b\right) d+\pi d^{2}\right\} 0.6 \sqrt{F_{c}}\right] \delta
\end{aligned}
$$

ここで, $2 x+t>_{s} h$ 場合は（13）式の第 1 項を ${ }_{s} T_{y}$ $\left\{2{ }_{s} h-\frac{\left({ }_{s} h-t\right)^{2}}{4 x}-\frac{\left({ }_{s} h-t\right)^{2}}{2_{b} h_{w}^{\prime}}\right\} \cos \alpha$ とすればよい。

はり端接合部の全塑性曲げモーメント ${ }_{j} M_{\rho}$ は，はり の断面内の応力分布が図一17(d) であれば，(14）式と なる。

$$
\left.\left.{ }_{j} M_{p}=l_{b} b \cdot{ }_{b} t_{\lambda_{b}} h_{w}+{ }_{b} t_{f}\right)+{ }_{b} t_{w} \cdot{ }_{b} h_{w}^{2} / 6\right\}_{f} \sigma
$$

(14) 式の ${ }_{f} \sigma$ は，(12）式と（13）式が等しいとして 求めた $\sigma$ が最小となるように未知数 $x$ を決定すれば得 られる。

各試験体の解析結果を表一 5 に示す。奏験值と解析值 の比 $Q_{e} \cdot s /{ }_{j} M_{p}$ (ここで, $s:$ はりの加力点から鉄骨柱. フランジまでの距離である。) は $1.01 \sim 1.12$ (平均值 1.07) となり, 両者の対応は比較的良好である。なお, “解析では各試験体とも $2 x+t>_{s} h$ となり, はり端接合 部の全塑性耐力時には鉛直スチフナは全面引張降伏状態 となり，実験結果のひずみ挙動と対応している(図一16 (a) 参照)。また, 試験体 IR-10 e の柱鉄骨フランジの ひずみ分布は面外曲げ挙動を示し, 降伏線位置の解析侣 とひずみ分布の対応は比較的良好である（図一16(b) 参照)。

\section{（2）はり端接合部の最大耐力}

はり端接合部の最大耐力を全塑性耐力の評価式を㹡張 して評価する。すなわち，i．柱鉄骨ウエブおよび鉛直 スチフナの引張降伏域の ${ }_{w} T_{y}$ および ${ }_{s} T_{y}$ の代わりに ${ }_{w} T_{t}$ $={ }_{c} t_{w \cdot{ }_{w} \sigma_{t}}$ および ${ }_{s} T_{t}={ }_{s} t \cdot{ }_{s} \sigma_{t}$ (ここで, ${ }_{w} \sigma_{t}$ および ${ }_{s} \sigma_{t}$ は それぞれ柱ウェブおよび鉛直スチフナ素材の引誩強さで ある。）とする。ii，柱鉄骨フランジの降伏線,$M_{\rho}$ の代 わりに ${ }_{s} M_{t}={ }_{c} t_{s}^{2} \cdot{ }_{s} \sigma_{t} / 4$ (ここで, ${ }_{f} \sigma_{t}$ は柱鉄骨ブランジ 素材の引張強さを意味する。）とする。iii. はり引張側 フランジが取り合う側の被覆コンクリート部分のコーン 状破壊面のせん断応力度として短期許容応力度 $0.6 \sqrt{F_{c}}$ の代わりに破壊応力度 $\sqrt{F_{c}}$ とする。

また，本実験でははり端接合部の最大耐力が，表一5 に示すとおり，はりの全塑性耐力以上であることを考虑 して，はりの断面内の応力分布を図一17(e) の亡おり仮 定する。すなわち，はりウェブは全塑性状態とし，はり フランジの平均応力度 ${ }_{s} \sigma$ を末知数としている。

はり端接合部の最大曲げモーメント ${ }_{j} M_{m}$ は, 全塑性 耐力の評価と同様に, はりの引張側のなす外部仕事と柱 の内部仕事が等しいとして求めた $\sigma$ が最小となるよう に末知数 $x$ を決定すれば（15）式により得られる。

$$
\left.{ }_{j} M_{m}={ }_{b} b \cdot{ }_{b} t{ }_{\lambda} h_{b} h_{b} t_{f}\right)_{s} \sigma+{ }_{b} t_{w} \cdot{ }_{b} h_{w}^{2} \cdot{ }_{b w} \sigma_{y} / 4 \cdots(15)
$$$$
\text { ここで, }{ }_{b w} \sigma_{y}: \text { はりゥエブ素材の降伏点である。 }
$$

各試験体の解析結果を表一 5 に示す。実験值之解析值 の比 $e_{e} \cdot s /{ }_{j} M_{m}$ は試験体 IR-10eでは 1.07 と両者の 対応は比較的良好である。しかし，IR-10 fでは 0.90 となり，解析值は㬰験值を過大評価している。この原四 に IR-10 f の柱鉄骨フランジとウェブの溶接がすみ肉溶 接であった点が挙げられるが，これについては今後の検 討課題である。なお, IR-10 s では最大耐力の解析值 ${ }_{j} M_{m} / s$ は実験值 $Q_{e} Q_{m}$ より大きくなり，これはIR-10s の最大耐力がはりウェブのせん断座屈で決定したことと 対応している。 
（3）・柱はり接合部パネルの耐力

$\mathrm{SRC}$ 規準 ${ }^{10)}$ によれば，本実験の場合，柱はり接合部 パネルの短期許容耐力 $Q_{A S}$ は（16）式となる。

$$
\begin{aligned}
& { }_{\rho} Q_{A S}={ }_{c} B \cdot{ }_{m c} d\left[\mathrm{MIN}\left\{0.3 F_{c}, 9\left(5+F_{c} / 100\right)\right\}\right. \\
& \left.+{ }_{w} p \cdot{ }_{h} \sigma_{y}\right] / 2+{ }_{s} Q_{p} \cdots
\end{aligned}
$$

ここで, ${ }_{c} B: \mathrm{SRC}$ 柱の幅, ${ }_{m c} d: \mathrm{SRC}$ 柱の主筋の応力 中心間距離, ${ }_{w} p:$ 帯筋比, ${ }_{n} \sigma_{y}:$ 帯筋の降伏点, ${ }_{s} Q_{p}$ : 接合部パネルの鉄骨部分の降伏せん断耐力である。

${ }_{s} Q_{p}$ として SRC 規準では柱鉄骨の直交フランジの効 果を考慮にいれず，(17.a) 式で評価している。

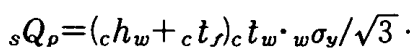

ここで， ${ }_{c} h_{w}$ : 柱ウェブせいである。

鉛直スチフナは純引張応力状態と仮定し（図一16 参 照)，直交フランジと鉛直スチフナが交叉する部分を剛 域と仮定して, ${ }_{s} Q_{0}$ に直交フランジの効果を考虑すれば, ${ }_{s} Q_{p}$ は柱軸力のない本実験の場合は (17.b) 式となる (図 -18 参照)。

$$
\begin{aligned}
& { }_{s} Q_{p}=\left({ }_{c} h_{w}+{ }_{c} t_{f}\right)_{c} t_{w} \cdot{ }_{w} \sigma_{y} / \sqrt{3}+\left.\operatorname{MIN}\right|_{c} t_{\rho} \cdot{ }_{c} b^{2} \cdot{ }_{s} \sigma_{y} / \\
& \left({ }_{b} H-\left({ }_{b} t_{f}+{ }_{s} h\right)\right), 2_{c} b \cdot{ }_{c} t_{\rho^{\prime}}{ }_{s} \sigma_{y} / \sqrt{3}, 2_{s} h \cdot{ }_{s} t \\
& { }_{s} \sigma_{y} \sin \alpha
\end{aligned}
$$

右辺第 2 項の第 1,2 の式は，鉛直スチフナの取り合 う部分を剛域と考え，直交フランジが両端で面内曲げの 全塑性曲げモーメントに達する値，および，直交フラン ジがせん断降伏するときの值をそれぞれ意味する。また， 第 3 の式は鉛直スチフナが引張降伏するときに直交する フランジが負担するせん断耐力を意味する。ただし，鈆 直スチフナの幅 $\left.{ }_{s} h\right)$ が本実験より広い場合, ここで用 いた仮定が妥当であるかは今後の検討課題である。

各試験体について。Q なお，括弧にはり端に作用する荷重に換算した値をす。 表一 5 および図一15(d) に示す $Q_{b^{-}}{ }_{a} \gamma$ 曲線より，(16) および (17.a) 式より求めた接合部パネルの短期許容耐 力は $Q_{b}{ }^{-}{ }_{a} \gamma$ 曲線の剛性が低下する荷重と対応し, (16) および (17.b) 式により求めた耐力は接合部パネルが 全面降伏する荷重にほほ対応していると考えられる。

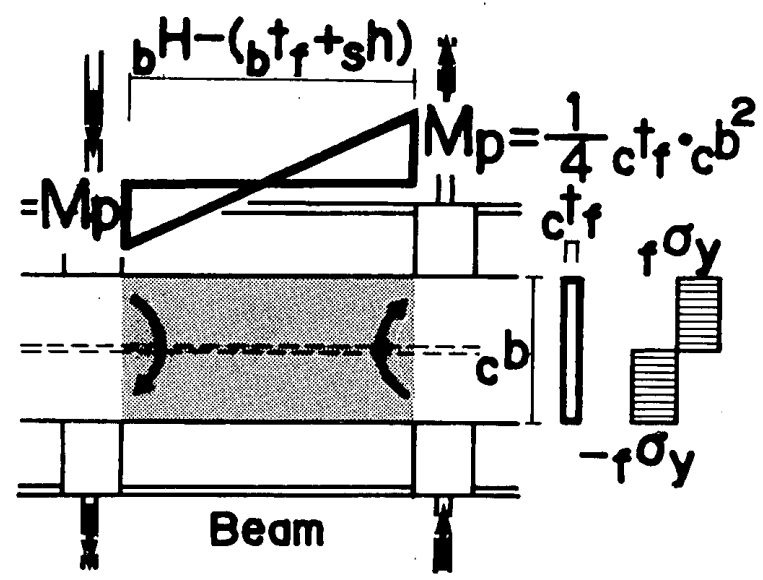

Fig. 18 Analytical Model of Connection Panel
なお，SRC 柱が一般化累加強度式による終局曲げ而 力となるときのはり端に作用する荷重は $81.8 \mathrm{tf}$ (IR$10 \mathrm{~s})$ から $86.0 \mathrm{tf}$ (IR-10f）となり, いずれの試験体 も柱は終局曲げ耐力に達していない。

\section{4. まとめ}

（1）柱が S, SC またはSRCで，はりがSの鉛直ス チフナ形式柱はり接合部の部分モデル試験の結果より,

i ）柱が充てんコンクリートの無いSの場合と充てん コンクリートのある SC, SRC の場合で, 接合部の応 力伝達機構が相違し, 鉛直スチフナは前者では面外曲げ 降伏し, 後者では引張降伏している。

ii）柱が SC, SRC の試験体では鈶直スチフナ厚さ および柱鉄骨フランジ厚さを厚くすると接合部耐力が上 昇するが，鈆直スチフナ幅は特定の幅以上に広げても接 合部耐力の上昇は期待できない。

iii）柱の構造形式に応じた接合部の全塑性耐力の評価 式を降伏線理論に基づいて提案し，また，それらを抁張 して最大耐力を評価する方法を示した。なお，各試験体 の耐力評価值は実験値と比較的良好な対応を示した。

（2）柱がSRC，はりがSの鉛直スチフナ形式の十字 形・柱はり接合部実験の結果より,

i ）はり端接合部の全塑性耐力は, 部分モデル試験の 結果と同様，鉛直スチフナ厚さおよび柱鉄骨フランジ厚 さを厚くすると上昇する。また， SRC 柱とはりフラン ジ接合部ははりフランジの引張側と圧縮側で局部変形性 状に大きな差異は認められない。

ii）はり端接合部の全塑性耐力および最大耐力を, 部 分モデル試験と同様な手法により, 評価する方法を示し た。なお, 各試験体の耐力評価值は実験值と比較的良好 な対応を示した。

iii） SRC 規準に示される接合部パネルの短期許容耐 力は接合部パネルの履歴曲線で剛性が低下する荷重と対 応する。なお，上記に柱鉄骨の直交フランジの効果を考 慮すれば接合部パネルの全塑性耐力がほぼ評価できる。

ただし，成果（2）は小数の十字形・柱はり接合部実 験結果より得られたものであり, 今後さらに実験資料を 蓄積して検討を加える必要がある。

なお，本研究は $1988 ， 1989$ 年度文部省科学研究費補 助金, 一般研究 C (課題番号 63550405 , 研究代表者: 森 田耕次）によるものである。また，実験は千葉大学・工 学部・建築工学実験棟および (株) 横河橋梁製作所・研 究所で行った。関係各位に深甚の謝意を表する。

\section{参考文献}

1）日本建築学会：鉄骨鉄筋コンクリート構造計算規準・同 解説, 1975 年版

2）森田耕次，横山幸夫，平岡秀章，石井 匠：鉄骨鉄筋 ב ンクリート柱・鉄骨はり接合部の鉛直スチフナ補強に関 
する研究 (その 1 , 実験 (I ) の計画及び考察)，(その 2 : 結果の考察), 日本建築学会大会学術講演梗概集 (九州), C構造 II, pp. 1583-1586

3）森田耕次, 浦等, 植野良二：柱はり接合部のスチフ ナ補強に関する実験的研究，日本建築学会構造系論文報 告集, 第 376 号, pp. 30-40, 昭和 62 年 6 月

4）森田耕次, 江波戸和正, 渡辺 仁, 山本 昇, 安田博和, 里見孝之：箱形断面柱-H形断面はり接合部のダイアフラ 么補強に関する研究一接合部降伏耐力の評洒一, 同上, 第 388 号, pp. 100-111, 昭和 63 年 6 月

5）日本建築学会：各種合成構造設計指針・同解説, 1985 制 定

6) Stone, William C. and Carino, Nicholas J. : Deformation and Failure in Large-Scale Pullout Tests, ACI JOURNAL, Proceedings V. 80 , No.6, Nov. -Dec. pp. 501-513, 1983

7) Cannon, R. W., Godfrey, D. A. and Moreadith, F. L. :
Guide to the Design of Anchor Bolts and Other Steel Embedments, CONCRETE INTERNATIONAL DESIGN AND CONSTRUCTION, Vol.3, No.7, pp. 2841, JULY 1981

8）加藤 勉, 佐藤邦昭, 遠山幸三, 中村嘉宏, 佐伯俊夫, 山田俊一：複合構造に於ける鋳鋼製 SPLIT TEE 接合部 に関する研究 (その3) 接合部耐力の評価式, 日本建筑 学会大会学術講演梗概集 (関東), pp 2777-27r8, 昭和 59 年 10 月

9) Kato, Ben : Beam-to-Column Connection Research in JAPAN, Journal of the Structural Division, ASCE, Vol. 108, No.ST2, pp. 343-360, February 1982

10）日本建築学会：鉄骨鉄筋コンクリート構造計算涀準・同 解説, 1987 年版

(1989 年 12 月 10 日原稿受理, 1990 年 5 月 8 日塖用決定) 